\title{
Oligosaccharides in Dahlia Tuber
}

\author{
by Shizuo HatToRI* and Mitsuhiko SATô**
}

Received April 24, 1963

Since the discovery of inulin from Jerusalem artichoke ${ }^{1)}$, it has been suggested that some compounds, which resemble inulin, but unlike it, have a great solubility in water and aqueous ethanol, should exist in plant kingdom ${ }^{2,31}$. Bacon and Edelman ${ }^{4}$ demonstrated that artichoke and other members of Compositae contain at least seven non-reducing oligosaccharides with Rfs lower than that of sucrose, which c nsist chiefly of fructose unit but possess also glucosyl residue. In parallel with this work, five oligosaccharides were isolated from the tuber of artichoke, and followings were established $^{5)}$. 1) These saccharides contain one glucose unit and certain numbers of fructose unit, 2) the ratios fructose to glucose are $1,2,3$ and so on in order of Rf values, and 3) their reaction to Raybin test showed the existence of sucrosyl bond ( $\alpha$-D-glucopyranosido-1, 2- $\beta$-fructofuranosidic bond) somewhere in their molecule.

The position of glucosyl rest in the molecule, however, has not yet been thoroughly elucidated, although from rather indirect evidence it has been supposed to be at the terminal of each sugar. In our work, six non-reducing oligosaccharides were isolated from the dahlia tuber which also contains inulin, and identified with those of artichoke, and the postulated position of glucosyl residue was also determined.

\section{Material and Methods}

Extraction of the oligosaccharides: About $100 \mathrm{~g}$ dahlia tuber (Dahlia variabilis) were scrubbed in water and disintegrated in a blendor with $100 \mathrm{~m} l$ of water. In order to prevent the action of polyphenoloxidase which caused discoloring, KCN was added up to a final concentration of $0.005 \mathrm{M}$. The mash obtained was squeezed through double folded gauze and centrifuged at $3000 \mathrm{~g}$ to remove cellular debris. The supernatant was saturated with lead acetate and the precipitate was discarded, and the remaining lead in the solution was removed by hydrogen sulfide treatment. The solution thus obtained was concentrated in vacuo to about one fifth of the original volume. A large amount of inulin in the solution was precipitated by adding ethanol and the precipitate was discarded.

Separation of the oligosaccharides: The separating method of the oligosaccharides was essentially the same as that of Dedonder ${ }^{5)}$ for the artichoke saccharides. About $100 \mathrm{~g}$ cellulose powder were heated with $300 \mathrm{ml} 15 \%$ acetic acid on a boiling water bath for three hours and the acid was removed by washing several times with a large volume of hot water. The treated powder, dried in the air and then suspended in ether (dried over anhydrous $\mathrm{Na}_{2} \mathrm{SO}_{4}$ ), was poured into a tube $54 \mathrm{~cm}$ in height and $3 \mathrm{~cm}$ in diameter. On to the cellulose column, from which ether was allowed to evaporate, $10 \mathrm{ml}$ of the extract were applied and after the water evaporated, a solvent of $n$-butanol-ethanol-1\% ammonia $(7.5: 0.75: 1.75, \mathrm{v} / \mathrm{v})$ was passed at a rate of $3 l \mathrm{a}$ day. Every $5 \mathrm{ml}$ fractions were gathered using a fraction collector, and the progress of the elution was paperchromatographically followed. Fractions containing the same

*, ** Department of Botany, Faculty of Science, University of Tokyo, Hongo, Tokyo, Japan.

* Present address: Okayama University, Tsushima, Okayama, Japan. 
saccharide were combined and concentrated in vacuo to syrup, which was then treated with active charcoal for removal of colored substances. Each of the resulting clear syrup was dried in a desiccator to white amorphous mass. In order to purify it, it was dissolved in methanol and the precipitate occurring by adding ether was collected. Crystallization was, however, unsuccessful because of the great hygroscopicity.

Paperchromatography: On Whatman No. 1 filter paper were applied test solutions and developed with $n$-butanol-acetic acid-water $(4: 1: 2, \mathrm{v} / \mathrm{v})$ or water saturated phenol. When better separations of the saccharides were desirable, descending or multiple chromatography was applied.

The spray reagents were as follows: i) benzidine trichloroacetic acid ${ }^{4}$ was used for the detection of all the saccharides, both reducing and non-reducing, ii) Horrocks' reagent $^{6)}$ is positive to reducing sugars, but not to non-reducing, iii) resorcinol dissolved in concentrated sulfuric $\operatorname{acid}^{7}$ ) is a reagent to detect free and combined fructose, and iv) Raybin test ${ }^{8)}$ gives a blue color to the saccharides that contain sucrosyl residue in the molecule.

Estimation of the saccharides: Fructose ${ }^{9)}$ and glucose ${ }^{10)}$ were estimated according to the literature. The determination of the ratio fructose/glucose was performed as follows. $2-3 \mathrm{mg}$ of each sample were hydrolyzed completely in $5 \mathrm{ml}$ of $15 \%$ acetic acid for $15 \mathrm{~min}$. on a boiling water bath, and the solution was then shaken with an equal volume of ether more than seven times to remove acetic acid. The acid-free solutions were adjusted to $12 \mathrm{~m} l$ with water, and $10 \mathrm{~m} l$ were used for titrimetric estimation of glucose and $1 \mathrm{ml}$ for colorimetric estimation of fructose. Experiments were run three times.

\section{Results}

Chromatographic aspects of the oligosaccharides: When the extract of dahlia tuber was developed by descending chromatography, more than ten separated spots were observed (Fig. 1 and Table 1), which were all detectable with benzidine trichloroacetic acid. The upper two were regarded as fructose and glucose from their $\mathrm{Rf}$ values and colors to some of the spray reagents. The authors would like to propose the names II to the substance situating below glucose, III to the one just below II, and so on. The spots lower than II were all positive to resorcinol, while they were negative to Horrocks' reagent, showing that they are fructose-containing saccharides of non-reducing nature.

According to French and Wild ${ }^{11)}$, logarithm of a function, Rf/(1-Rf) against the degree of polymerization (hexose units per molecule) is to form a straight line, when a group of saccharides are successively formed by addition of a definite glycosyl unit, as shown in galactan, dextran, inulin and amylose series. Fig. 2 shows that such a relationship is also the case with the dahlia oligosaccharides at least from III to $\mathrm{X}$.

Separation and characterization of the saccharides: From the dahlia tuber extract, amorphous saccharides from II to VII were isolated.

The evidence that the oligosaccharides have sucrosyl part(s) somewhere in the molecule was given by an experiment in which partial hydrolysis under a mild condition (5\% acetic acid at $100^{\circ}$ ) was undertaken for III and V and the appearance of sucrose was shown in their hydrolysates in an early stages of hydrolysis (Fig. 3). 


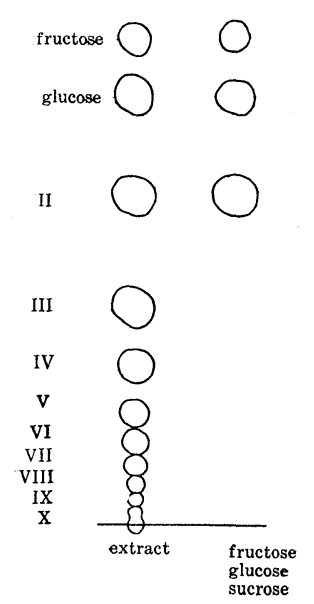

A

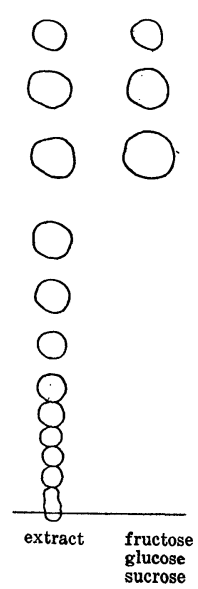

B

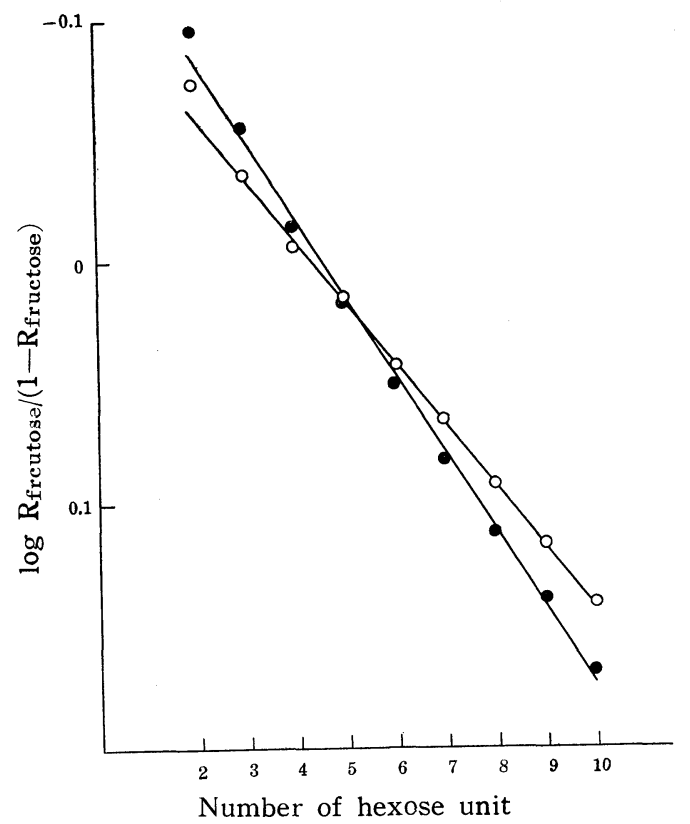

Fig. 2. Relationship between the degree of polymerization and a function $\log \mathrm{R}_{\text {fructose }} /(1-$ R fructose). - $\bigcirc-$, with $n$-butanol/acetic acid/ water (descending); —- with water saturated phenol (descending). method with $n$-butanol/acetic
with water saturated phenol.

Table 1. Some properties of the oligosaccharides.

\begin{tabular}{|c|c|c|c|c|c|c|c|c|}
\hline \multirow[t]{2}{*}{ Substance } & \multicolumn{3}{|c|}{ Rf values* } & \multicolumn{2}{|c|}{$\begin{array}{l}\text { Reaction to } \\
\text { the reagents** }\end{array}$} & \multirow{2}{*}{$\begin{array}{c}\text { mg separated } \\
\text { (amorphous } \\
\text { sample) }\end{array}$} & \multirow{2}{*}{$\begin{array}{c}\text { Raybin } \\
\text { test }\end{array}$} & \multirow{2}{*}{$\frac{\text { Fructose }}{\text { Glucose }}$} \\
\hline & A & B & $\mathrm{C}$ & $\mathrm{i}$ and $\mathrm{iii}$ & ii & & & \\
\hline II & .101 & .664 & .366 & + & - & 28 & + & 0.94 \\
\hline III & .061 & .441 & .275 & + & - & 42 & + & 2.02 \\
\hline IV & .040 & .322 & .223 & + & - & $20 * * *$ & + & 2.81 \\
\hline V & .028 & .226 & .171 & + & - & 51 & + & 4.00 \\
\hline VI & .020 & .170 & .133 & + & - & 26 & + & 5.18 \\
\hline VII & & .123 & .104 & + & - & 23 & + & \\
\hline VIII & & .089 & .079 & + & - & & & \\
\hline IX & & .065 & .060 & + & - & & & \\
\hline $\mathrm{X}$ & & .048 & .047 & + & & & & \\
\hline $\mathrm{XI}$ & & .033 & & + & & & & \\
\hline
\end{tabular}

* A, Rf values when developed by ascending method with $n$-butanol/acetic acid/water; B Rfructose by descending with the same solvent; $C$, R $\mathrm{R}_{\text {fructose }}$ by descending with water saturated phenol. $\quad * *$ Reagents: i, benzidine trichloroacetic acid; ii, Horrocks' reagent; iii, resorcinol in concentrated sulfuric acid. $\quad * * *$ In this case, a significant amount overflowed caused by some hindrance of the collector.

The positive reaction to Raybin test was another support for the presence of the sucrosyl part(s). 
Ratios of fructose/glucose were determined for the oligosaccharides from II to VI, and the values are shown in Table 1, which are approximately 1 for II, 2 for

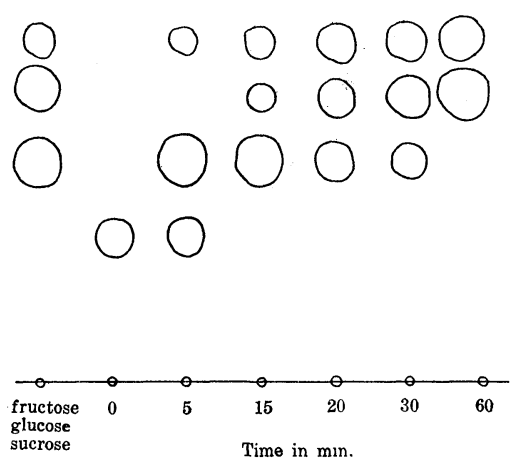

(A)

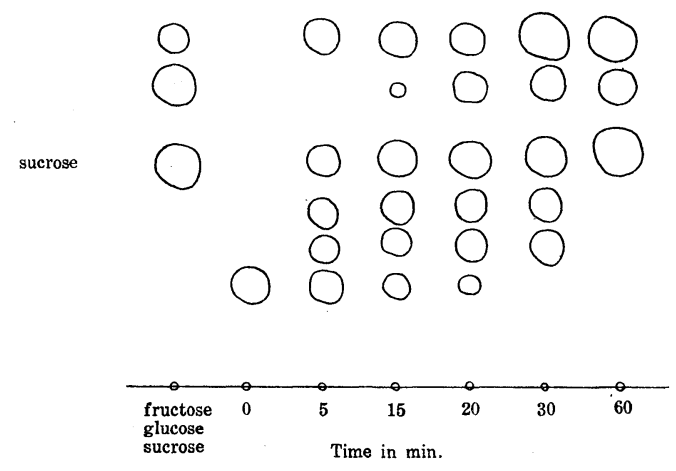

(B)

Fig. 3. Paperchromatogram of the hydrolysates of III (A) and V (B) resulting from a partial hydrolysis under a mild condition. Developed with water saturated phenol at first, and then with $n$-butanol/acetic acid/water.

III, 3 for IV, and so on, although an expected value 6 could not be obtained for VII. The oligosaccharides seem, therefore, to have one glucose and $(n-1)$ fructose unit(s).

When the above information is applied to III, its probable structure may be regarded as either glucose-fructose-fructose or fructose-glucose-fructose. In view of the non-reducing nature of all the oligosaccharides, glucosyl unit should link with an adjacent fructosyl unit through a sucrosyl bond, so that the structure of III should be either glucose- $\alpha-1,2-\beta$ fructose-?, 2 - $\beta$-fructose or fructose- $\beta-2,1-\alpha$-glucose-?, 2 - $\beta$-fructose. An evidence for the first possibility came from an experiment, in which an $\alpha$-glucosidase, that was isolated from commercial Takadiastase according to the method of Nystrom et al. ${ }^{12)}$, was incubated with $2 \mathrm{mg}$ of III at $\mathrm{pH} 7$ for 18 hours at $30^{\circ}$, and the liberation of glucose was paperchromatographically demonstrated (Fig. 4).

Also in the other oligosaccharides, the glucosyl residue seems to situate at the end of the molecule, because IV, VI and VII gave glucose and the rest possibly composed solely of fructosyl units, and because, as shown before, they are members of a series of oligosaccharides arising. by successive addition of a fructosyl residue.

\section{Discussion}

The chromatographic experiments show the existence in dahlia tuber of a series. of non-reducing oligosaccharides. From the facts that the complete hydrolysis of six isolated saccharides gave only glucose and fructose, the ratios fructose/glucose are 
$1,2,3$ and so on in order of their $\mathrm{Rf}$ values, and the function, $\log \mathrm{R}_{\text {frucsose/( }}$ - Rfructosa) against the degree of polymerization makes a straight line in these saccharides, they seem to be on an analogous series, in which each saccharide is formed from the smaller one by stepwise addition of a fructosyl unit. These sugars have a sucrosyl residue somewhere in their molecule, as was shown by partial hydrolysis and also by the Raybin test.

These informations coincide with those already described about the oligosaccharides in Jerusalem artichoke tuber ${ }^{4,5}$. The dahlia tuber appears, therefore, to possess the same oligosaccharides as those in the artichoke tuber. The position of glucosyl residue in the sac harides of artichoke, however, has not yet been thoroughly elucidated, although from rather indirect evidence it has been supposed to situate at the end of each saccharide ${ }^{4,5}$. From an experiment in the present work, in which an $\alpha$ glucosidase acted on these oligosaccharides and an appreciable amount of glucose was observed, the postulated hypothesis on the terminal situation of the glucosyl residue was directly evidenced.

The oligosaccharides in dahlia tuber, and possibly those in artichoke tuber, therefore, may be regarded in order of their Rf values as sucrose (II), fructosylsucrose (III), difructosylsucrose (IV) and so on. Although the determination of the nature of the linkage between two fructosyl residues was not done, it is likely, in conformity with a hypothesis on the structure of inulin proposed by Hirst et al. ${ }^{13}$, that they may be connected with a 1,2-linkage, because these oligosaccharides seem to be precursors of inulin. If this is the case, the substance III may coincide with kestose which has already been found in Lolium perenne $e^{14)}$ and rye $^{\mathrm{e}^{(5)}}$.

\section{Summary}

1) The dahlia tuber possesses a series of non-reducing oligosaccharides, which are composed of one glucose unit and certain numbers of fructose unit and have a sucrosyl part somewhere in the molecule, and they seem to be identical with the oligosaccharides which have already been found in Jerusalem artichoke tuber.

2) The position of glucosyl residue, which has not been definitely elucidated in the artichoke oligosaccharides, was determined in the present study to situate at the end of each sugar. The oligosaccharides in dahlia tuber, and possibly those in artichoke tuber, may be, therefore, sucrose, fructosyl sucrose (kestose), difructosylsucrose and so on.

\section{References}

1) Rose, V., Gehlens Neues Allg. J. Chem. 3: 21 (1804).

2) Tanret, C., Bull. Soc. Chim. 9: 200, 227, 622 (1898). 3) Schlubach, H. H., and Knoop, H., Liebigs Ann. 497: 208 (1932); 504: 19 (1933). 4) Bacon, J.S. D., and Edelman, J., Biochem. J. 48: 114 (1951). 5) Dedonder, R., Bull. Soc. Chim. Biol. 34: 144 (1952). 6) Horrocks, R. H., Nature 164: 444 (1949). 7) Seliwanoff, T., Ber. deutsch. chem. Ges. 20: 181 (1887). 8) Raybin, H., J. Amer, Chem. Soc. 55: 1933 (1933). 9) Roe, J., J. Biol. Chem. 107: 16 (1934). 10) Macleod, M., and Robison, R., Biochem. J. 42: 238 (1948). 11) French, D., and Wild, C. M., J. Amer. Chem. Soc. 75: 2612 (1953). 12) Nystrom, C. W., Williams, B. L., and Wender, S. H., J. Amer. Chem. Soc. 72: 76 (1950). 13) Hirst, E. L., McGilvary, D. I., and Percival, E. C., J. Chem. Soc. 268 (1950). 14) de Walley, H. S., Intern. Sugar J. 54: 127 (1942); Schlubach, H. H., Lübers, H., and Borowski, H., Liebigs Ann. 599: 229 (1955). (1958).

15) Schlubach, H. H., and Koew, H. O. A., ibid. 614: 126 
服 部 静夫・佐 藤 満 彦: ダリアの塊根にふくまれる少糖類

1) ダリアの塊根には，1 分子のグルコースと数分子のフルクトースから構成され，分子のどこかにショ 䌅部分をるつ一系列の非還元性の少糖類のふくまれていることがわかった。 これらの少糖類は，すでに記 載されているキクイモの塊䒝の少糖類と特なじものとかんがえられる.

2) しかしキクイモの少糖類では，分子内のグルコースの位置がまだ確定されていない，本実験でそれ は, 各少糖類の分子の末端に位置することがわかった。 したがって, ダリアの塊根にふくまれる一系列の 少糖類は(执そらくキクイモの塊茎のそれも), ショ糖にはじまり, 各少糖類の末端のフルクトースに，フル クトース残基が一分子ずつ連続的にくわわってでき，イヌリンにいたっているるのとかんがえられる。（東 京大学理学部植物学教室) 